\title{
Obtaining the Factors Affecting Bioeconomy
}

\author{
Indra MUIZNIECE ${ }^{1 *}$, Lauma ZIHARE ${ }^{2}$, Dagnija BLUMBERGA ${ }^{3}$ \\ ${ }^{1-3}$ Institute of Energy Systems and Environment, Riga Technical University, Azenes iela 12/1, Riga, \\ LV-1048, Latvia
}

\begin{abstract}
At the scientific level it is being increasingly recognised that the concept of bioeconomy has transdisciplinary nature, but there is still no consensus on key factors that would accelerate the development of sustainable bioeconomy. Therefore, within the framework of this study, certain factors, their interactions and link strength with bioeconomy from a scientific perspective are identified. A bibliometric analysis method is used to achieve this aim in such a way that the keyword information on the published scientific literature in relation to the bioeconomy is translated into quantifiable data. This way the relevance of the bioeconomy factors and the strength of their direct and mutual interaction with the bioeconomy will be determined. From this study it can be concluded that the strongest links with bioeconomy are for biomass, bioenergy, biotechnology and innovations. No significant link was found for such factors as: behaviour, production, pollution and infrastructure. It becomes clear that, in the view of scientists, the decisive role in the development of the bioeconomy resulting from the use of bio resources in the higher value-added production is for technologies. These results are used to build a framework for a system dynamics model that can be used for modelling bioeconomy development scenarios in the future.
\end{abstract}

Keywords - Bibliometric analysis; bio-based economy; bio-economy; scientometric analysis; sustainable development; transdisciplinarity; VOSviewer

\section{INTRODUCTION}

The concept of bioeconomy has become the main driver of economic development in recent years, despite the parallel development of other concepts that directly or indirectly affect the bioeconomy. The flourishing of the bioeconomy is linked to the launch of the European Union bioeconomy strategy in 2012 [1] and the updated strategy in 2018 [2].

At the scientific level, it is being increasingly recognised that the concept of bioeconomy has a transdisciplinary nature [3]-[8]. It is clear that in order to accelerate development of the bioeconomy, the following aspects should be recognised: development of bioeconomy, including meaningful use of resources, understanding bioeconomy key factors, their influence and link strength. So far, some studies have been carried out on the factors affecting bioeconomy [3], [9]. There is still no consensus on key factors that would accelerate development of sustainable bioeconomy. For example, in the previous study of authors [3], 22 factors affecting development of bioeconomy had been detected. In another study authors [9] had determined the main types of barriers for bioeconomy innovation: financial, policy, organizational, technology, resource, environmental and climate, behavioural and market. However, the results of these research studies had not quantified the significance of these factors, neither had they brought clarity to the question which of them are the most important.

\footnotetext{
* Corresponding author.

E-mail address: indra.muizniece@rtu.lv
} 
It is also clear that opinions on this issue differ between the parties involved [10], [11]. For example, the opinions of scientists, policy makers, entrepreneurs and society vary. The view of all of these parties should be considered in order to find the best possible solution for realistic theoretical assumptions.

This study has been carried out to generate methodology with the aim to identify the factors, their interactions and how strongly they are related to the bioeconomy from scientific perspective in the beginning and moving towards the holistic approach. A bibliometric analysis method is used to achieve this aim. Therefore, keywords on the published scientific literature in relation to the bioeconomy are translated into quantifiable data. This way the relevance of the bioeconomy factors and the strength of their direct and mutual interaction with the bioeconomy are determined. These results are used to build a framework for a system dynamics model. The model can be used to create bioeconomy development scenarios in the future.

An article on bioeconomy that have used bibliometric analysis has already been published [11]-[13], but it does not analyse the interrelation of keywords and is not considered in the context of the factors affecting bioeconomy. Additionally, the results from these bibliometric analysis studies have neither been used to develop a new methodology nor for further, in-depth and expanded studies. The methodology based on bibliometric analysis that has been used in this study can be considered innovative. The results of bibliometric analysis are not only used for primary analysis, but also as data for determining the strength of direct and indirect impact of bioeconomy factors. The results of the method could also be used for identifying the bioeconomy system and for indicators selection.

Previously, a number of studies to identify indicators have been carried out. The indicators that characterise the bioeconomy, which mainly distinguish such groups of indicators as environmental, social [14], and economic, [15]-[18], are the three main pillars of sustainability [19]. Other studies, for example, [20], have been supplemented by a group of technology indicators. But not all studies include indicators for innovation and research for the sustainable development of the bioeconomy [15], [20], although their essential role is recognised [15], [16] and confirmed by the EU Bioeconomy strategy [2]. For example, the project "BioEconomy Regional Strategy Toolkit" (2014) [16] integrates bioeconomy and innovation related indicators into economic and social criteria groups. Conversely, Natural Resources Institute Finland (LUKE), in the study [21] recognised that the indicator "Investment in research and innovations" is one of the most suitable key indicators under all bioeconomy objectives. In this aspect, the characterisation of bioeconomy indicators through the prism of the bioeconomy related factors and their interactions had not been conducted. That is why this study is considered to be a step in moving closer to the holistic exploration of the bioeconomy process.

\section{METHODOLOGY}

In order to determine which factors influence the development of the bioeconomy, and to evaluate their directly impact and interacting, a combined method is used (Fig. 1). Inputs from the previous studies have been used, and the results will be used for future research as well as modelling of different scenarios.

In the first phase of the methodology bibliometric (scientometric) analysis was performed, using VOSviewer version 1.6.11. First of all, (part A) author keywords related to the bioeconomy topic were selected from more than 7000 scientific publications indexed in SCOPUS database. The search for keywords in the abstract, title and keywords sections was 
conducted. The 4 most popular keywords used to select bioeconomy are bioeconomy, bio-economy, bio economy, bio-based economy. Previously conducted bioeconomy studies, such as Sanz-Hernandez et al. [12], also use these keywords. Firstly, 100 author used keywords with the strongest links that directly match the bioeconomy theme were selected.

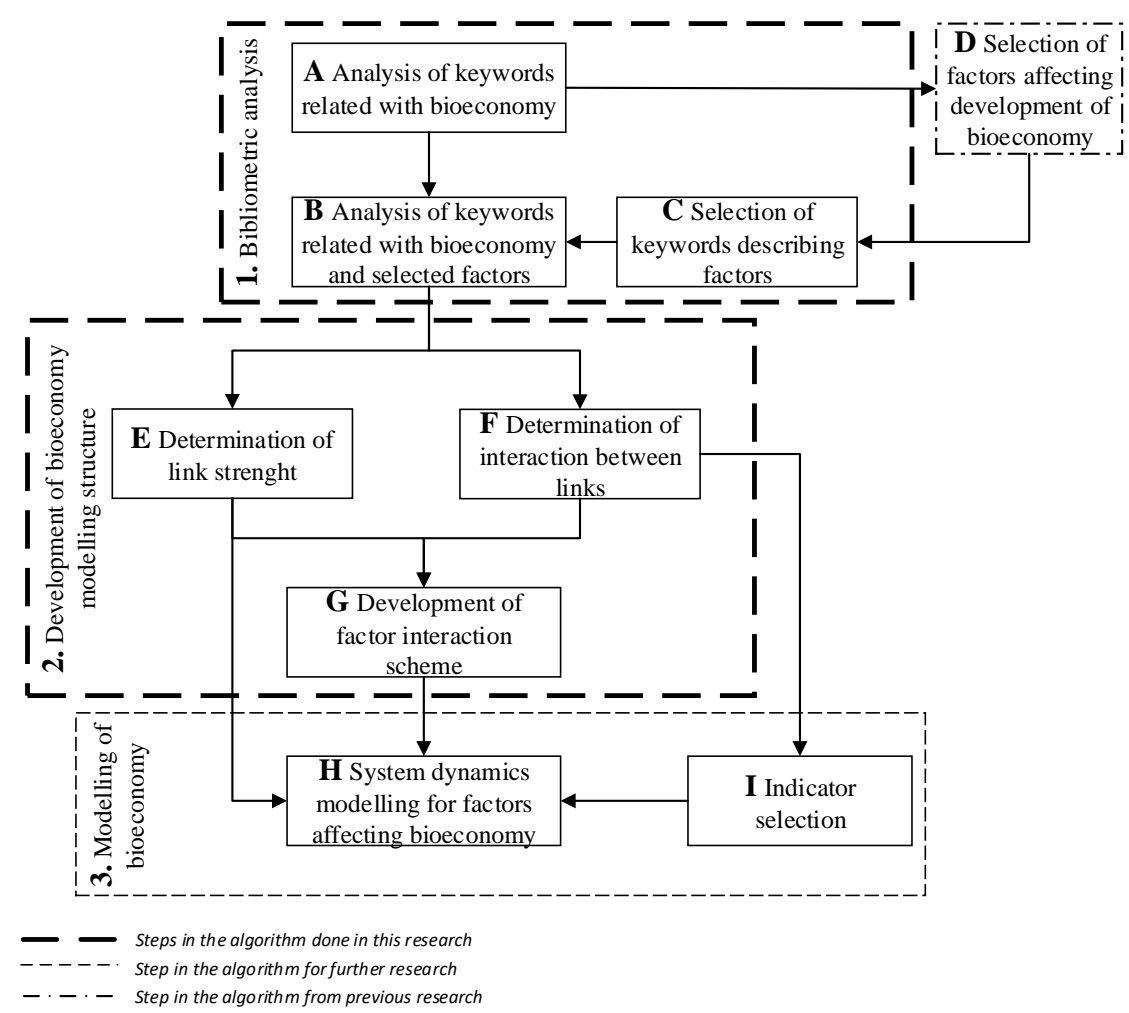

Fig. 1. Methodology algorithm.

Based on the authors' previous study (Phase D), the direct link of 24 factor keywords to the bioeconomy was examined (Phase B). These 24 factors have been selected on the basis of the previous research by the authors: land, waste, prosperity, climate change, bio-resources, non-renewable resources, human resources/population, research and innovation, energy consumption, education/knowledge, politics, health, behaviour, technology, water, natural environment, consumption, financial resources, economic growth, food/feed, production, pollution, infrastructure, primary renewable resources [3], assessing the factors that could influence the development of the bioeconomy, taking into account the natural and man-made environment and processes. One to four related keywords (Table 1) for each factor have been selected (Phase $\mathrm{C}$ ), with which the relevant factor may be labelled. Using 4 bioeconomy designation keywords ("bioeconomy" OR "bio-economy" OR "bio economy" OR "bio-based economy") and the keyword group for each factor (for example, first factor, "land" OR "soil" OR "ground") documents selected in the abstract, title and keyword section of the searched keywords have been selected in the SCOPUS database. From these documents, author keywords have been selected, and then used to determine the strength of the interrelations 
and links between the keywords that describe the factors affecting the bioeconomy with the help of VOSviewer.

\section{TABLE 1. DOCUMENTS WITH BIOECONOMY RELATED FACTORS AND KEYWORDS SELECTED FROM SCOPUS DATABASE}

\begin{tabular}{|c|c|c|c|}
\hline No. & Factor & Related keywords selected & $\begin{array}{l}\text { Documents found in } \\
\text { SCOPUS database }\end{array}$ \\
\hline 1 & Production & Production, manufacturing & 884 \\
\hline 2 & Research and innovations & Research, innovations, science & 858 \\
\hline 3 & Bio resources & Bio resources, biomass & 661 \\
\hline 4 & Energy, energy consumption & Energy consumption, energy & 651 \\
\hline 5 & Technology & Technologies & 549 \\
\hline 6 & Policy & Policy, politics & 477 \\
\hline 7 & Food and feed & Food, feed & 454 \\
\hline 8 & Education and knowledge & Education, knowledge & 309 \\
\hline 9 & Waste & Waste, rubbish, garbage & 304 \\
\hline 10 & Land, land use & Land, soil, ground & 251 \\
\hline 11 & Environment & Natural environment, environment & 212 \\
\hline 12 & Climate changes & Climate changes, greenhouse gas emissions & 178 \\
\hline 13 & Water & Water & 174 \\
\hline 14 & Financial resources & $\begin{array}{l}\text { Financial resources, finances, money, } \\
\text { investments }\end{array}$ & 167 \\
\hline 15 & Health & Health & 160 \\
\hline 16 & Consumption & Consumption & 142 \\
\hline 17 & Primary renewable resources & $\begin{array}{l}\text { Primary renewable resources, renewable } \\
\text { resources }\end{array}$ & 133 \\
\hline 18 & Human resources, population & Human resources, population & 111 \\
\hline 19 & Economic growth & Economic growth & 75 \\
\hline 20 & Pollution & Pollution & 69 \\
\hline 21 & Non-renewable fossil resources & $\begin{array}{l}\text { Non-renewable resources, fossil resources, } \\
\text { mineral resources }\end{array}$ & 66 \\
\hline 22 & Infrastructure & Infrastructure & 56 \\
\hline 23 & Behaviour & Behaviour, behavior & 48 \\
\hline 24 & Wellbeing & Welfare, wellbeing & 28 \\
\hline
\end{tabular}

As it can be seen in Table 1, the most significant number of documents related to bioeconomy contain the terms production and research, and innovation. But this does not indicate that these factors are key factors that can accelerate sustainable development of bioeconomy. Therefore, a more detailed bibliometric analysis was performed, using the VOSviewer computer program.

In both cases, 100 keywords with the highest link strength have been selected to determine the structure and closeness of the system. The strength of the links is calculated by the 
VOSviewer program, which indicates the number of publications overlapping the use of two keywords.

Using the results of the first part of the methodology, the structure of the bioeconomy model has been developed in the second part of the methodology. Using keywords, the relevance of the links (step E) and their interaction (Phase F) in the investigated system have been determined. This leads to the main directions on which the science focuses in the context of bioeconomy and the factors that should work in practice with legislation, science and financial help. Based on the results of the $\mathrm{E}$ and $\mathrm{F}$ stages of the methodology, a factor interaction scheme has been established. This scheme will be the basis for future research $\left(3^{\text {rd }}\right.$ part of methodology) to perform bioeconomy development modelling, for example, system dynamic modelling (Phase $\mathrm{H}$ ). To do this, it is necessary to identify the characteristic indicators (Phase I) of the most significant links of the bioeconomy system. Taking into account that Phase $I$ is a section of future research, this study will select only one of the factors as an example. This example can be used in the future for other factors affecting bioeconomy.

As it was mentioned before, this research is conducted from the scientists' point of view, using bibliometric analysis methodology of scientific literature. Therefore, results show main topics and ways how scientists see development of bioeconomy. The factors can have positive and negative impact on the development of bioeconomy, causing acceleration or stagnation of the development of bioeconomy. Detection of the character of each factor is left for further studies.

\section{RESUlTS AND DisCUSSION}

About 2000 scientific articles from the SCOPUS database have been used in the general bioeconomy analysis. This kind of analysis is complicated by the fact that the bioeconomy term in articles can be written in at least 4 different ways. Therefore, keywords' direct link strength with bioeconomy can be only indicative. It is shown in the Annex Fig. 1 that the majority of bioeconomy studies are related to sustainability, biomass, biorefinery and biofuels. Unfortunately, these leading factors (except for biomass, which is a resource, and biofuels, which is a product) are concepts and cannot be used as factors affecting bioeconomy. In addition, most of these keywords are technological processes or products. This shows that the interest of the bioeconomy concept, including innovative products and their manufacturing technologies, is becoming more common in the scientific community. Although such network cannot be used as a basis for building and analysing a bioeconomy system with a holistic approach. Another solution should be found that would answer the following research question: what factors and their interaction influence the development of bioeconomy and to what extent? 

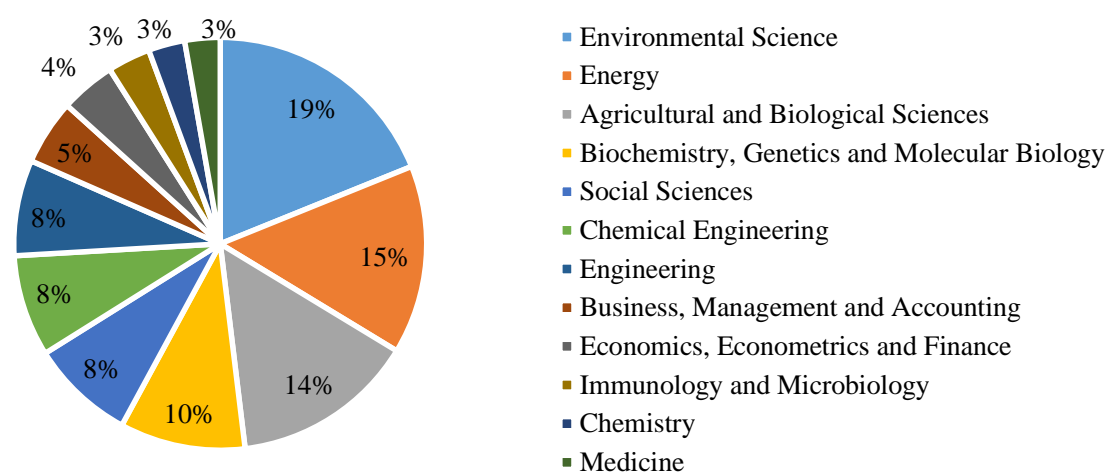

Fig. 2. Leading science sectors in which SCOPUS indexed articles on bioeconomy have been developed.

The pre-selected 24 factors and their relation to the bioeconomy have been used to determine the strength and interrelation of their direct relationship. Relevant scientific publications in SCOPUS database have been selected (more than 7000), and only 24 keywords and their interlinkages have been considered. Interdisciplinary nature can be found in the analysis of the sectors in which these publications have been published. As shown in Fig. 2, the leading sectors are environmental science, energy, agriculture and biology. Other sectors are also relatively represented, showing that the bioeconomy is interlinked and has interdisciplinary nature.

By selecting the set of 24 factor-related keywords (see Annex Fig. 2) the strongest link with bioeconomy was found to be "Biomass", "Bioenergy", "Biotechnology" and "Innovations". No significant links were found for the factors "Behavior", "Production", "Pollution", and "Infrastructure". Among the links of factors in the context of bioeconomy, the strongest link is between Bioenergy and Biomass. Out of these results, the main factors influencing the development of the bioeconomy are clearly identified and can be used for modelling and for the development and analysis of bioeconomy scenarios.

Looking at the 24-factor system by selecting 100 keywords with the strongest links (see Annex Fig. 3), it is clear that the decisive role in the development of the bioeconomy resulting from the use of bio resources in the production of higher value-added products is in technology (industrial biotechnology, synthetic biology, metabolic engineering etc.).

For the 24-factors system that influence the development of bioeconomy, using the bibliometric analysis program VOSviewer, the strengths of the interlinks and the strengths of the links with bioeconomy have been determined for each factor as well as their relevance in the system (see Table 2). The relevance is expressed by the weight, the total of which in the system is 1 . 
TABLE 2. THE STRENGTH AND IMPORTANCE OF THE ANALYSED 24-FACTORS INFLUENCING BIOECONOMY

\begin{tabular}{|c|c|c|c|c|c|c|}
\hline No. & Factor & $\begin{array}{l}\text { Link strength } \\
\text { with bioeconomy }\end{array}$ & Weight & $\begin{array}{l}\text { Link strength } \\
\text { with another } \\
\text { factor }\end{array}$ & Weight & $\begin{array}{l}\text { Weights } \\
\text { difference, \% }\end{array}$ \\
\hline 1 & Health & 11 & 0.008 & 38 & 0.024 & -204.7 \\
\hline 2 & Environment & 34 & 0.024 & 115 & 0.073 & -199.9 \\
\hline 3 & Wellbeing & 8 & 0.006 & 24 & 0.015 & -162.0 \\
\hline 4 & Consumption & 10 & 0.007 & 28 & 0.018 & -151.0 \\
\hline 5 & Food and feed & 27 & 0.019 & 74 & 0.047 & -143.1 \\
\hline 6 & Land, land use & 32 & 0.023 & 83 & 0.053 & -131.0 \\
\hline 7 & Financial resources & 11 & 0.008 & 23 & 0.015 & -90.5 \\
\hline 8 & Research and innovations & 165 & 0.118 & 223 & 0.141 & -19.6 \\
\hline 9 & $\begin{array}{l}\text { Non-renewable fossil } \\
\text { resources }\end{array}$ & 8 & 0.006 & 8 & 0.005 & 12.7 \\
\hline 10 & $\begin{array}{l}\text { Primary renewable } \\
\text { resources }\end{array}$ & 58 & 0.042 & 55 & 0.035 & 15.7 \\
\hline 11 & $\begin{array}{l}\text { Energy, energy } \\
\text { consumption }\end{array}$ & 306 & 0.219 & 285 & 0.181 & 17.4 \\
\hline 12 & Education and knowledge & 44 & 0.032 & 39 & 0.025 & 20.6 \\
\hline 13 & Bio resources & 315 & 0.226 & 241 & 0.153 & 32.2 \\
\hline 14 & Policy & 88 & 0.063 & 60.5 & 0.038 & 39.7 \\
\hline 15 & Technology & 198 & 0.142 & 133 & 0.084 & 40.7 \\
\hline 16 & Waste & 24 & 0.017 & 16 & 0.010 & 41.8 \\
\hline 17 & Climate changes & 58 & 0.042 & 24 & 0.015 & 63.9 \\
\hline 18 & Water & 0 & 0 & 83 & 0.053 & - \\
\hline 19 & Economic growth & 0 & 0 & 15 & 0.010 & - \\
\hline 20 & $\begin{array}{l}\text { Human resources, } \\
\text { population }\end{array}$ & 0 & 0 & 10 & 0.006 & - \\
\hline 21 & Behaviour & 0 & 0 & 0 & 0 & - \\
\hline 22 & Production & 0 & 0 & 0 & 0 & - \\
\hline 23 & Pollution & 0 & 0 & 0 & 0 & - \\
\hline 24 & Infrastructure & 0 & 0 & 0 & 0 & - \\
\hline & Average: & 58.2 & $\sum 1.00$ & 65.7 & $\sum 1.00$ & \\
\hline
\end{tabular}

As shown in Table 2, the relevance of the links does not coincide with the importance of the direct relation to the bioeconomy in all cases. The biggest difference in weight is "Land, land use", "Wellbeing", "Health", "Environment", "Consumption", "Financial resources" and "Food and feed". For each of these 7 factors, greater importance is attached to interaction with other factors than to bioeconomy, although indirectly bioeconomy is most influenced by the following factors: "Energy, energy consumption", "Bio resources", "Technology" and 
"Research and innovations". It is also in line with the factors that are most relevant to the bioeconomy in this system, only the numerical values of the weights differ (the difference ranges from $17.4 \%$ to $40.7 \%$ ).

It has already been mentioned that 4 of the given factors (Behaviour, Production, Pollution, Infrastructure) did not find significant links with other factors in the common system. A significant direct link to the bioeconomy was not found in 3 other factors - "Human resources, population", "Water" and "Economic growth".

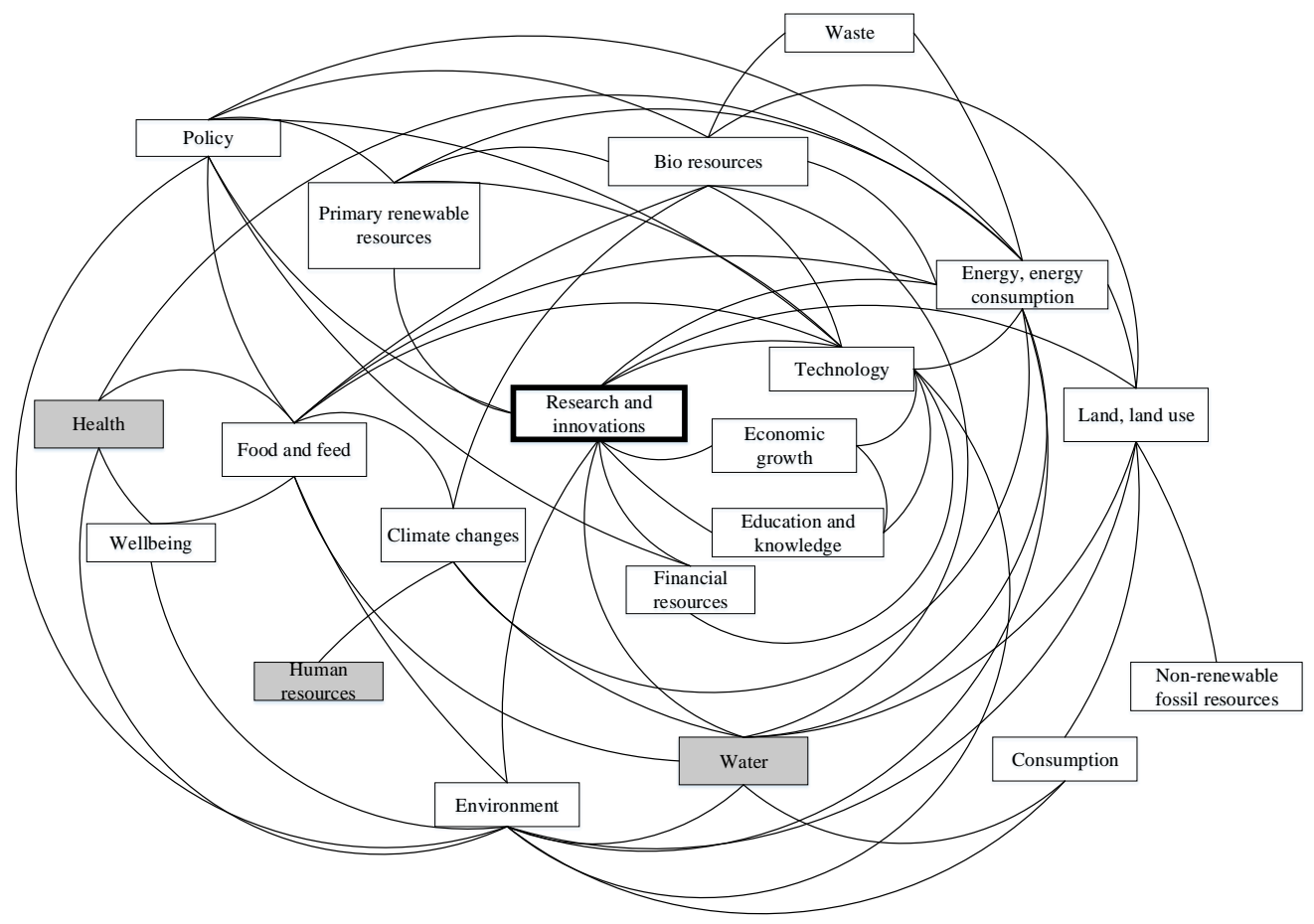

Factors that do not have significant direct link with bioeconomy

Fig. 3. Principal scheme of interaction between the factors influencing the development of bioeconomy.

The obtained results have been taken into account in order to create a scheme of interaction of the factors influencing the basic bioeconomy development (Fig. 3), which could be used to create a model for the analysis of bioeconomy development scenarios. It should be noted that this scheme is based on the current trends of scientific research on the bioeconomy. It is not excluded that there are other important links and factors that are not included here, which should be considered when the possibilities of bioeconomy development are estimated. To further develop the idea of this study, it is necessary to continue research in order to:

- Integrate the views of policy makers, entrepreneurs and the society to identify more objective links and factors influencing bioeconomy development;

- Direction of the links (the factors have mutual or only one-sided effect) and the strength of each direction link;

- To define what effect - positive or negative - this interaction creates; 
- To create a causal loop diagram and a dynamic hypothesis for the holistic bioeconomy system;

- To identify equations and regularities that characterize the interaction of factors and direct interaction with the bioeconomy;

- To develop a dynamic model, validate it on a national scale, and evaluate different development scenarios to identify the most effective solution and the factors that should be worked on to accelerate bioeconomy development.

System dynamics modelling is recognised as the most appropriate modelling method to continue the ongoing research in the intended direction, as it is a method of studying the dynamic development of complex systems that can be used to solve complex issues. Despite the fact that a professor of system dynamics Sterman believes that system dynamics is fundamentally interdisciplinary [22], [23], it can also be used to address transdisciplinary issues by putting together and analysing the opportunities and interests of society and science. System dynamics have been used for searching for solutions for very different and complicated problems. For example, it has been used to find a relative effect of growth of demand for energy services due to changes in income, energy consumption per unit of demand due to technological development, changes in electricity price and household income on household electricity consumption [24]. So far, there have been some studies in which system dynamics modelling has also been used to model bioeconomy, for example [25]-[28]. As far as the authors know, no bioeconomy modelling has been performed till now with such a wide range of influencing factors as this article suggests.

\section{TABLE 3. RESEARCH AND INNOVATION INDICATORS}

\begin{tabular}{|c|c|c|c|}
\hline & Input & Output & Indicators \\
\hline \multirow[t]{4}{*}{ Research } & Expenditure on the development of innovation & Implemented scientific projects & \multirow{12}{*}{$\begin{array}{l}\text { Return on } \\
\text { investment } \\
\text { in } \\
\text { innovation } \\
\text { Research } \\
\text { efficiency }\end{array}$} \\
\hline & Science attracted fund-raising & $\begin{array}{l}\text { Registered intellectual property } \\
\text { rights }\end{array}$ & \\
\hline & State support for science & Scientific publications & \\
\hline & Science personnel involved & & \\
\hline \multirow{4}{*}{$\begin{array}{l}\text { Research } \\
\text { and } \\
\text { innovations }\end{array}$} & State funding for innovation development & $\begin{array}{l}\text { Patent-Citations per Scholarly } \\
\text { Output }\end{array}$ & \\
\hline & Private funding for innovation development & $\begin{array}{l}\text { Intellectual property rights have } \\
\text { been sold }\end{array}$ & \\
\hline & $\begin{array}{l}\text { Attracted funds for financing the development of } \\
\text { innovations }\end{array}$ & & \\
\hline & $\begin{array}{l}\text { Workforce involved in the development of } \\
\text { innovation }\end{array}$ & & \\
\hline \multirow[t]{4}{*}{ Innovations } & $\begin{array}{l}\text { State funding for commercialization of } \\
\text { innovations }\end{array}$ & Number of innovative companies & \\
\hline & $\begin{array}{l}\text { Private financing for the commercialization of } \\
\text { innovations }\end{array}$ & Number of innovative companies & \\
\hline & $\begin{array}{l}\text { Attracted fund financing for commercialization } \\
\text { of innovations }\end{array}$ & $\begin{array}{l}\text { The added value of innovative } \\
\text { companies }\end{array}$ & \\
\hline & $\begin{array}{l}\text { Workforce involved in the commercialization of } \\
\text { innovations }\end{array}$ & Innovative products & \\
\hline
\end{tabular}


To build system dynamics model, each link should be expressed as mathematical equation and/or numerical values. Therefore, it is necessary to find the most appropriate indicators that characterise each link. Within this study, one factor is taken as an example, which is Research and Innovation (Table 3).

To obtain Research and innovations indicators "return on investment in innovation" and "research efficiency" directly in the context of the bioeconomy system, the indicators should be individually attributed to each related factor. That is a part of future studies of the work.

\section{CONClusion}

The study has analysed the most frequently used author keywords in more than 7000 scientific publications from SCOPUS database in relation with bioeconomy. The most relevant sectors related to bioeconomy from scientific view have been determined. In general, the study has shown that the strongest links with the bioeconomy are such factors as sustainability, biomass, biorefinery and biofuels.

Direct strength and their mutual closeness of 24-factor links, based on previous bioeconomy studies, found that the strongest links with bioeconomy are for biomass, bioenergy, biotechnology and innovations. No significant link was found in some factors, for instance, behaviour, production, pollution and infrastructure. Among the links between factors in the context of bioeconomy bioenergy and biomass are the strongest. Looking at this system more widely, it becomes clear that, in the view of scientists, the decisive role in the development of the bioeconomy resulting from the use of bio resources in the higher value-added production is technology (industrial biotechnology, synthetic biology, metabolic engineering etc.). The scheme of interaction of 20 factors influencing the basic bioeconomy development of this system has been developed, which can be used for further research and development of system dynamics model for analysis of bioeconomy development scenarios and determination of the most effective bioeconomy development.

\section{ACKNOWLEDGEMENT}

This research is funded by the Latvian Council of Science, project "Bioresources Value Model (BVM)", project No. lzp-2018/1-0426.

\section{REFERENCES}

[1] European Commission. Innovating for Sustainable Growth: A Bioeconomy for Europe. Communication from, the Commission to the European Parliament, the Council, the European Economic and Social Committee and the Committee of the Regions. European Commission, 2012.

[2] European Commission. A sustainable Bioeconomy for Europe Strengthening the connection between economy, society and the environment. Updated Bioeconomy Strategy. European Commission, 2018.

[3] Muizniece I., Blumberga D., Kubule A. Towards understanding the transdisciplinary approach of the bioeconomy nexus. Energy Procedia 2018:147:175-180. doi:10.1016/j.egypro.2018.07.052

[4] Lewandowski I. Bioeconomy. Shaping the Transition to a Sustainable, Biobased Economy. Springer, 2018.

[5] Haarich S. Bioeconomy development in EU regions. Mapping of EU Member States'/regions' Research and Innovation plans \& Strategies for Smart Specialisation (RIS3) on Bioeconomy. European Commission, 2017. doi:10.2777/84684

[6] Golembiewski B., Sick N., Broring S. The emerging research landscape on bioeconomy: What has been done so far and what is essential from a technology and innovation management perspective? Innovative Food Science and Emerging Technologies 2015:29:308-317. doi:10.1016/j.ifset.2015.03.006

[7] Schutte G. What kind of innovation policy does the bioeconomy need? New Biotechnology 2018:40:82-86. $\underline{\text { doi:10.1016/j.nbt.2017.04.003 }}$ 
[8] Pfau S. F., Hagens J. E., Dankbaar B., Smits A. J. M. Visions of Sustainability in Bioeconomy Research. Sustainability 2014:6(3):1222-1249. doi:10.3390/su6031222

[9] Muizniece I., Timma L., Blumberga D. Biotechonomy innovations development barriers in Latvia. Energy Procedia 2017:113:285-288. doi:10.1016/j.egypro.2017.04.067

[10] Vivien F.-D., Nieddu M., Befort N., Debref R., Giampietrode M. The Hijacking of the Bioeconomy. Ecological Economics 2019:159:189-197. doi:10.1016/j.ecolecon.2019.01.027

[11] Bugge M., Hansen T, Klitkou A. What Is the Bioeconomy? A Review of the Literature. Sustainability 2016:8:691. doi:10.3390/su8070691

[12] Sanz-Hernandez A., Esteban E., Garrido P. Transition to a bioeconomy: Perspectives from social sciences. Journal of Cleaner Production 2016:224:107-119. doi:10.1016/j.jclepro.2019.03.168

[13] Amato D. D., Droste N., Allen B., Kettunen M., Lahtinen K., Korhonen J., Leskinen P., Matthies B. D., Toppinen A. Green, circular, bio economy: A comparative analysis of sustainability avenues. Journal of Cleaner Production 2017:168:716-734. doi:10.1016/j.jclepro.2017.09.053

[14] Ronzon T., M'Barek R. Socioeconomic Indicators to Monitor the EU's Bioeconomy in Transition. Sustainability 2018:10(6):1745. doi:10.3390/su10061745

[15] SAT-BBE Consortium. Tools for evaluating and monitoring the EU bioeconomy: Indicators, 2013.

[16] BERTS. Criteria and Indicators describing the regional bioeconomy. Cambridge, UK, 2014.

[17] Egenholf V., Bringezu S. Conceptualization of an indicator system for assessing the sustainability of the bioeconomy. Sustainability 2019:11(2):443. doi:10.3390/su11020443

[18] Joint Research Centre, European Commission. Getting (some) numbers right. Derived economic indicators for the bioeconomy. Proceedings of a side-event at the EUBCE, Copenhagen, 15 May 2018. doi:10.2760/2037

[19] Purvis B., Mao Y., Robinson D. Three pillars of sustainability: in search of conceptual origins. Sustainability Science 2019:14(3):681-695. doi:10.1007/s11625-018-0627-5

[20] Iriarte L. et al. S2Biom Project. D5.4. Consistent Cross-Sectoral Sustainability. Criteria \& Indicators. Final Report, 2015.

[21] Lier M., Aarne M., Karkkainen L., Korhonen K. T., Yli-Viikari A., Packalen T. Synthesis on bioeconomy monitoring systems in the EU Member States - indicators for monitoring the progress of bioeconomy. Natural Resources and Bioeconomy Studies 2018:38:44.

[22] Sterman J. D. System dynamics modelling: Tools for learning in a complex world. California Management Review 2001:4:8-25. doi:10.2307/41166098

[23] Sterman J. D. Business Dynamics, System Thinking and Modeling for a Complex World. Massachusetts Institute of Technology Engineering Systems Decision, 2002.

[24] Bariss U., Bazbauers G., Blumberga A. Blumberga D. System Dynamics Modeling of Households' Electricity Consumption and Cost-Income Ratio: A Case Study of Latvia. Environmental and Climate Technologies 2017:20(1):36-50. doi:10.1515/rtuect-2017-0009.

[25] Gravelsins A., Blumberga A., Blumberga D., Muizniece I. Economic analysis of wood products: System dynamics approach. Energy Procedia 2017:128:431-436. doi:10.1016/j.egypro.2017.09.023

[26] Allena-Ozolina S., Bazbauers G. System dynamics model of research, innovation and education system for efficient use of bio-resources. Energy Procedia 2017:128:350-357. doi:10.1016/j.egypro.2017.09.051

[27] Azis R., Blumberga A., Bazbauers G. The role of forest biotechonomy industry in the macroeconomic development model of the national economy of Latvia: An in-depth insight and results. Energy Procedia 2018:147:25-33 doi:10.1016/j.egypro.2018.07.029

[28] Blumberga A., Bazbauers G., Davidsen P. I., Blumberga D., Gravelsins A., Prodanuks T. System dynamics model of a biotechonomy. Journal of Cleaner Production 2018:172:4018-4032. doi:10.1016/j.jclepro.2017.03.132 


\section{ANNEX}

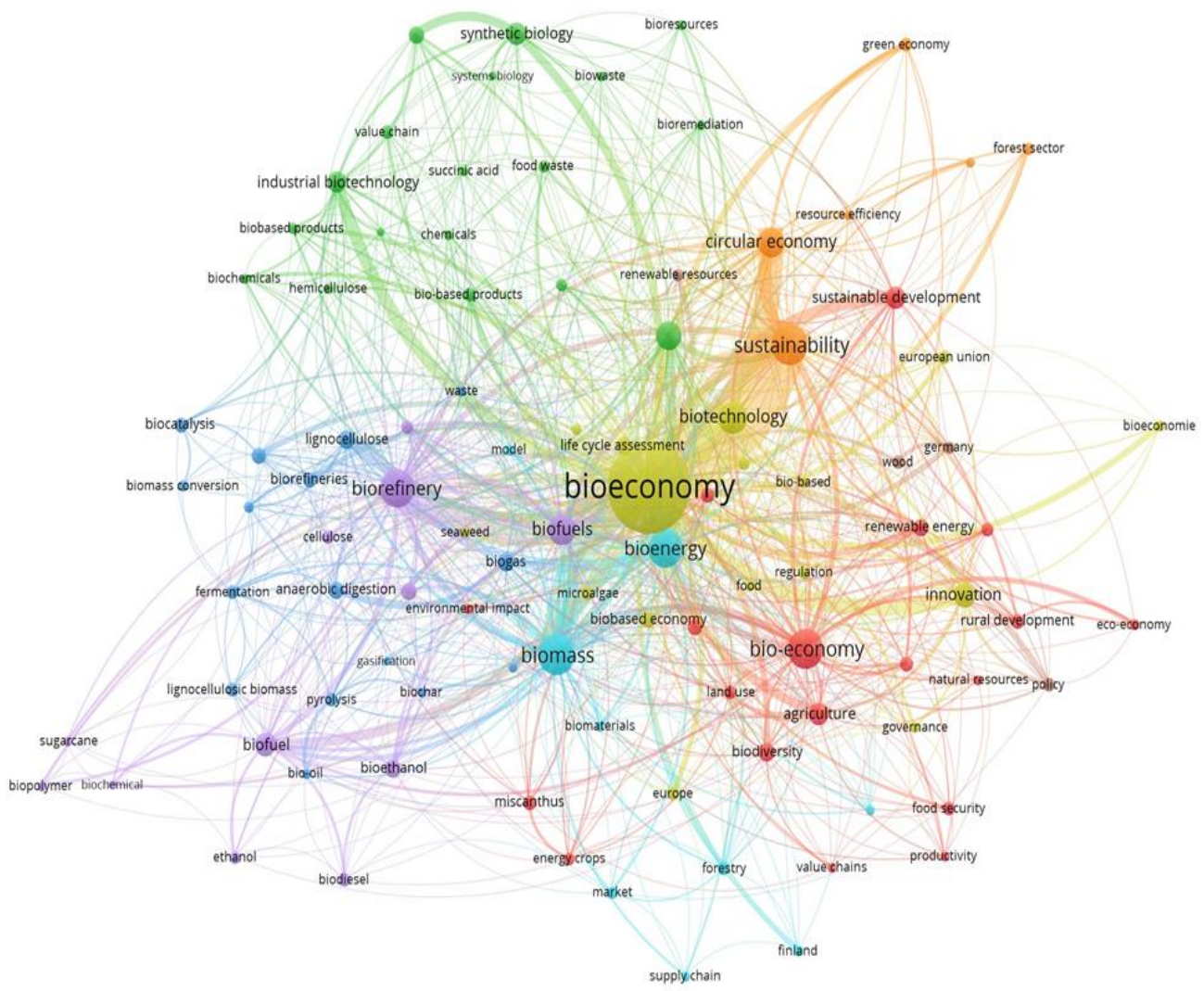

Fig. 1. Top 100 keywords from SCOPUS scientific publications related with bioeconomy. 


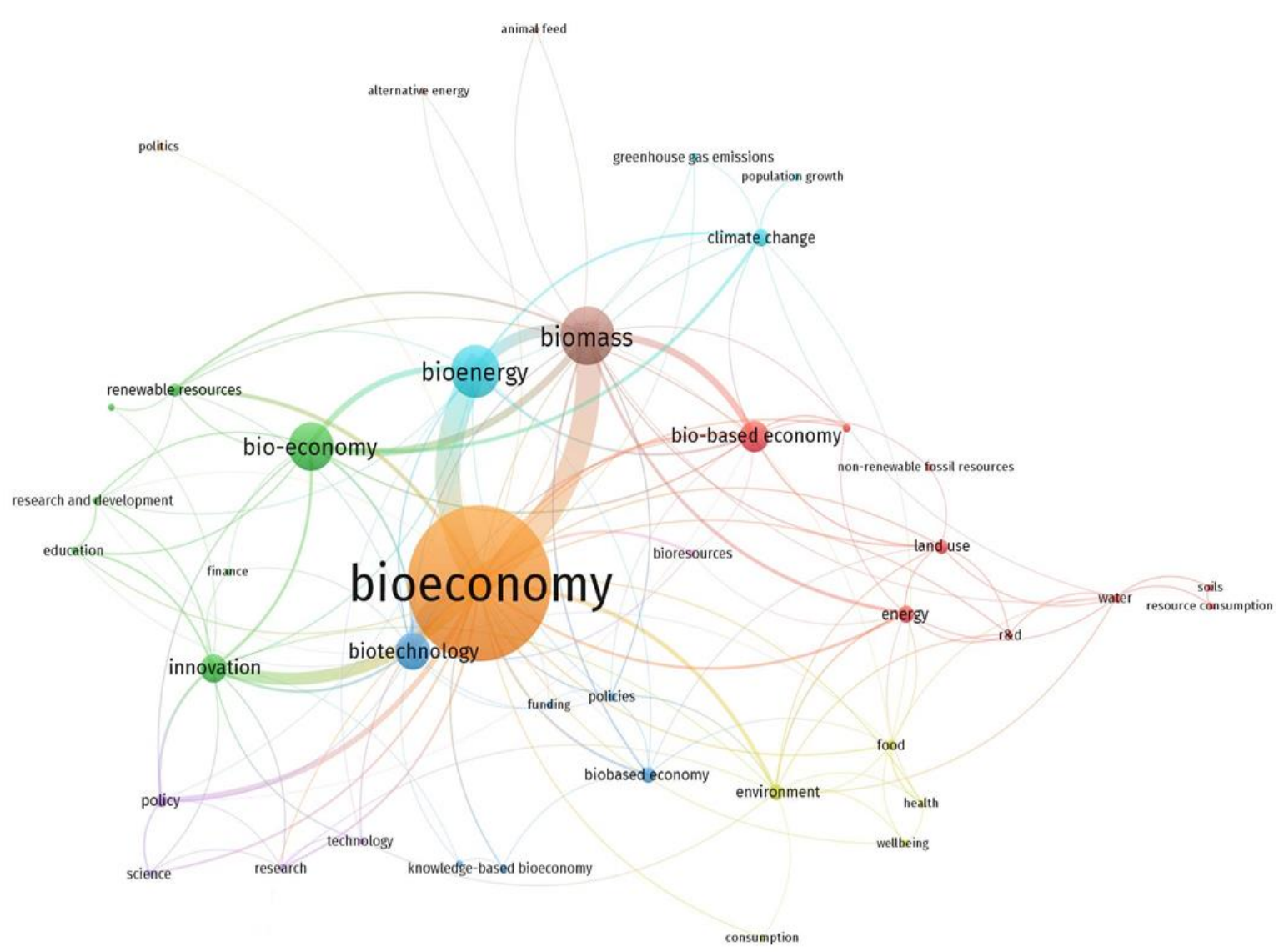

Fig. 2. Links from SCOPUS scientific publications with selected 24 bioeconomy affecting factors. 


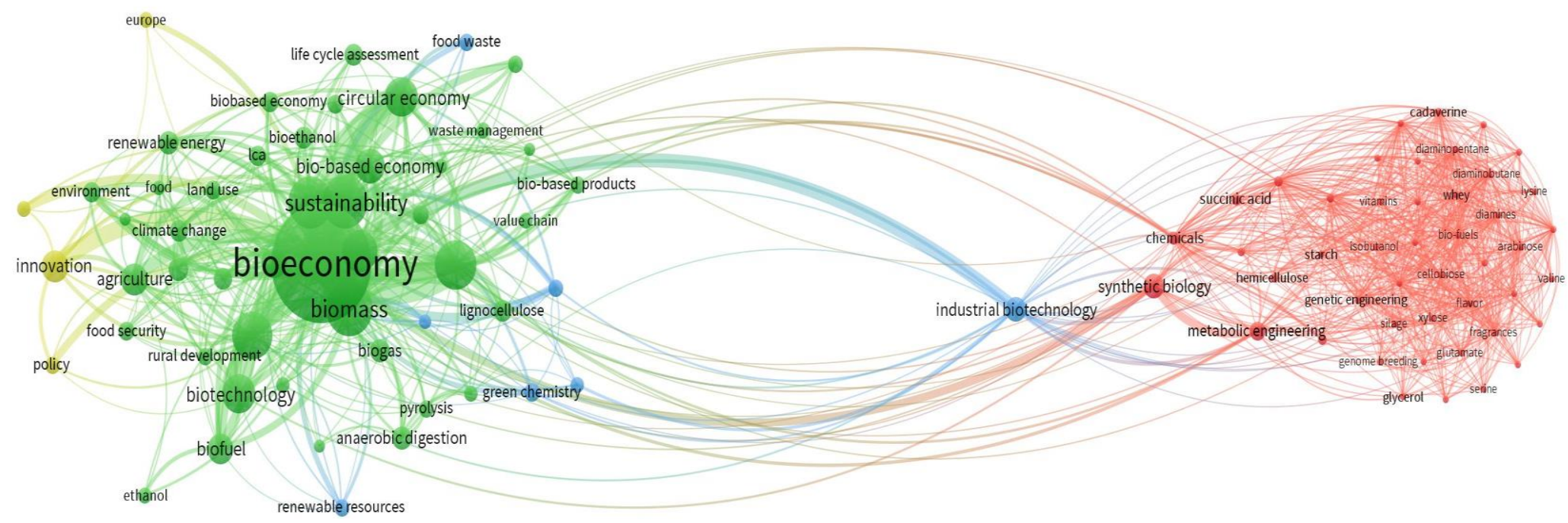

Fig. 3. Top 100 keywords with strongest links from SCOPUS scientific publications about bioeconomy related with selected 24 bioeconomy affecting factors. 

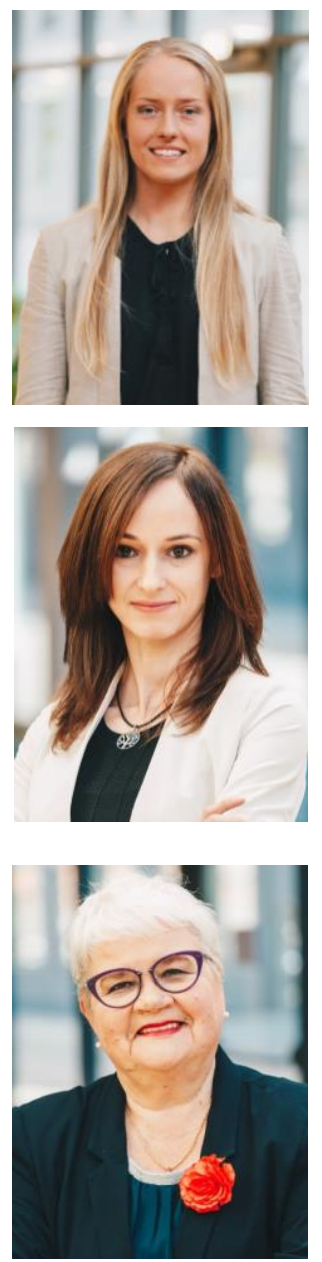

Indra Muizniece received a Professional Bachelor's degree in Land Use from Latvia University of Life Sciences and Technologies. In 2013 she received a Master's degree in Environmental Science from Riga Technical University. In 2018 she received the Ph.D. degree from Riga Technical University, Institute of Energy Systems and Environment.

Indra Muizniece is a researcher and lecturer of the Institute of Energy Systems and Environment of Riga Technical University. Her main research area includes biotechnology, bio-resources, sustainable use of resources and creation of products with higher added value.

Lauma Zihare, M. sc., Riga Technical University, Institute of Energy Systems and Environment. Lauma Zihare acquired Bachelor's degree of Social sciences in Management in 2011 at University of Latvia and Master's degree in Environmental Science in 2016 at Riga Technical University. She has continuous working experience as s Researcher in Riga Technical University. Currently she is a PhD student at Institute of Energy Systems and Environment. The main research area is invasive species application in bioeconomy.

Dagnija Blumberga, Dr. habil. sc. ing., professor, director of the Institute of Energy Systems and Environment, Riga Technical University. Her two-step doctoral degree "Condensing Unit" was defended in Lithuanian Energy Institute, Kaunas (1988). Doctor Habilitus Thesis "Analysis of Energy Efficiency from Environmental, Economical and Management Aspects" was prepared in Royal Institute of Technology (KTH) Stockholm (1995) and was defended in Riga Technical University (1996).

Dagnija Blumberga has been part of academic staff of Riga Technical University since 1976 and director of Institute of Energy Systems and Environment since 1999.

The main research area is renewable energy resources. She has participated in different local and international projects related to energy and environment as well as an author of more than 200 publications and 14 books.

ORCID ID: https://orcid.org/0000-0002-9712-0804 